\title{
MYOFIBRILLAR MYOPATHY WITH DESMINOPATHY IN A FOUR AND A \\ HALF YEAR OLD CHILD
}

${ }^{2}$ Diana Militaru, ${ }^{1}$ Alexandra Maris, ${ }^{2}$ Mariela Militaru, ${ }_{s}^{1}{ }^{2}$ Mihai Militaru, ${ }^{2}$ Dan

Gheban

${ }^{1}$ The Emergency Hospital for Children Cluj -PICU

2The University of Medicine and Pharmacy Cluj-Student, Lector Assistant Professor,Lector

\section{Objectives and Introduction:}

Myofibrilar myopathies are a group of neuromuscular disorders which are characterized by the abnormal intracellular accumulation of an intermediate filament called desmin ,that subsequently leads to muscle weakness Desmin is the chief intermediate filament of skeletal and cardiac muscle, maintains the structural and functional integrity of the myofibrils, and functions as a cytoskeletal protein linking $\mathrm{Z}$ bands to the plasma membrane The illness presents with lower limb muscle weakness slowly spreading to involve truncal, neck-flexor, facial, bulbar and respiratory muscles. Skeletal myopathy is often combined with cardiomyopathy manifested by conduction blocks and arrhythmias resulting in premature sudden death

The disease usually presents in adulthood but in some rare cases it has been described with an early onset in children

The objective of this presentation is to establish the diagnostic pattern of muscle weakness in children

\section{Methods and Materials:}

We present the case of a patient admitted in our word for generalized hypotonia, respiratory insufficiency, fever, holosystolic murmur, galop rhythm.

\section{Results:}

A 4 and a half year old patient is admitted in the PICU for fever, tachypnea, severe respiratory insufficiency, generalized cyanosis, generalized hypotonia ( especially axial hypotonia),systolic murmur, dolichocephaly, high arched palate, adenoid facies, moderate muscular atrophy, week osteotendinous reflexes, History- positive for neonatal hypoxia, neonatal sepsis with Escherichia Coli, recurrent lower respiratory tract infections which required orotracheal intubation and mechanical ventilation, generalized hypotonia from birth- floppy infant Biological findings: pronounced inflammatory syndrome; severe respiratory acidosis, radiological findings: bilateral pulmonary condensations

The case is interpreted as bronchopneumonia, chronic respiratory insufficiency, undiagnosed possible myopathy

The patient requires orotracheal intubation and mechanical ventilationsubsequently a tracheostomy is performed

The neurological consult indicates the possibility of spinal muscular amiotrophy- mutations on SMN1 came back negative.

Serum enzimes ( CK MM,MB,BB)- normal values

Electromyography: decreased action potentials with a low amplitude $\rightarrow$ suggestive for muscle involvement

Echocardiography : hypertrophic cardiomiopathy with right decompensationthe patient required digoxin iv, subsequently po

Muscle biopsy: : The examined material has the structure of a striated muscle biopsy.The biopsy was examined in ice and paraffin sections, using the colorations hematoxylin eosin, tricrom Masson and immunohistochemical for desmin.The usual coloration shows the presence of atrophic fibers throughout the normal fibers, with a polygonal shape and sometimes slightly rounded shape. These fibers have a central or internalized nucleus. There are also images of focal fiber necrosis( polymorphonuclear in the interstitium and internalization of nuclei) and focal regeneration (basophil cytoplasma, vacuolized hyperplastic nuclei). Tricrom Masson coloration shows in a large number of apparently normal fibers proteic hyaline deposits ( visible in the ice sections) and also discrete focal vacuolizations of the cytoplasma ( visible in hematoxylin eosin paraffin sections). The coloration for desmin shows the normal inclusions in the $\mathrm{Z}$ discs of type 2 fibers, and the abnormal inclusion in type 1 fibers.At this level the desmin has a granular deposit with a fingerprintlike pattern.

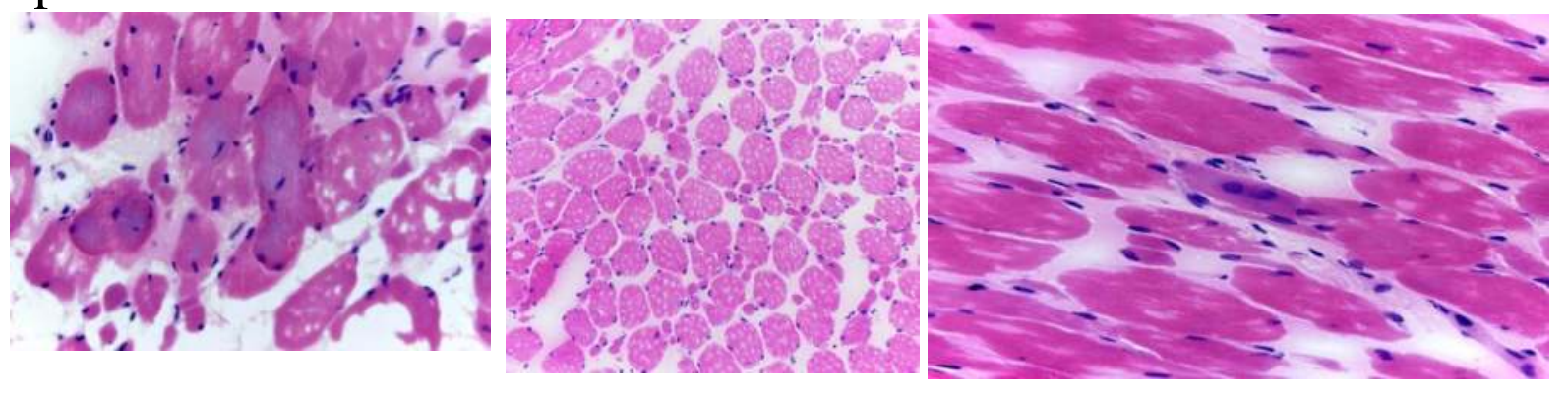

\begin{tabular}{|c|c|c|}
\hline Hypotonia Pattern & $\begin{array}{l}\text { Associated } \\
\text { pathologies }\end{array}$ & Organ Involv \\
\hline $\begin{array}{l}\text { Central hypotonia } \\
\text { Especially axial } \\
\text { hypotonia } \\
\text { Live reflexes }\end{array}$ & $\begin{array}{l}\text { Chromozomal } \\
\text { implication } \\
\text { Inborn erorrs of } \\
\text { metabolism } \\
\text { Cerebral } \\
\text { disgenesis,spinal or } \\
\text { cerebral trauma }\end{array}$ & $\begin{array}{l}\text { Central Nervou } \\
\text { System }\end{array}$ \\
\hline $\begin{array}{l}\text { Generalized hypotonia } \\
\text { that spears the } \\
\text { diaphragm,facial } \\
\text { muscles, the pelvis and } \\
\text { the sphincters }\end{array}$ & $\begin{array}{l}\text { Spinal muscular } \\
\text { amiotrophy }\end{array}$ & Motor Neuron \\
\hline $\begin{array}{l}\text { Involvment of the distal } \\
\text { muscle groups, asthenia } \\
\text { and fatigue }\end{array}$ & $\begin{array}{l}\text { Peripheral } \\
\text { Neuropathies }\end{array}$ & Nerv \\
\hline $\begin{array}{l}\text { Involvment at a grater } \\
\text { rate of the oculomotor } \\
\text { and bulbar muscles }\end{array}$ & $\begin{array}{l}\text { Miastenia gravis like } \\
\text { syndromes, Infantil } \\
\text { Botulism }\end{array}$ & $\begin{array}{l}\text { Neuromuscular } \\
\text { Junction }\end{array}$ \\
\hline $\begin{array}{l}\text { Hypotonia is the } \\
\text { first sign } \\
\text { Proximal muscles } \\
\text { Weak } \\
\text { osteotendinous } \\
\text { reflexes } \\
\text { Articulatory } \\
\text { retractions }\end{array}$ & $\begin{array}{l}\text { Congenital } \\
\text { myopathies } \\
\text { Metabolic } \\
\text { myopathies } \\
\text { Congenital } \\
\text { muscular distrophy } \\
\text { Congenital } \\
\text { myotonic distrophy }\end{array}$ & Muscle \\
\hline
\end{tabular}

\section{Conclusions}

:The aspect that was described in the muscle biopsy together with the clinical and biological data, suggested a fibrillar myopathy with associated desminopathy.The desminopathy has more than one pattern, in this case being pattern number 3 The particularity of this case was represented by the difficulty of the diagnosis of a fibrillar myopathy at such an early age. Also the patient had skeletal muscle involvement associated with heart muscle involvement that required treatment ( after one year of digoxin po the treatment was withdrawn). In the present day the patient is 13 years old, he is homeschooled, he has a permanent tracheostomy tube and requires sleep mechanical ventilation.He is walking and does not need wheelchair, he also rides a bike. 